\title{
The Comparison of Strategies for Physiological Recovery Coach and Province Level Fencing Athlete during the Pandemic Covid-19
}

\author{
Anisa Nur Fadilah ${ }^{1}$, Nor Syafikah ${ }^{1}$, Rini Ismalasari ${ }^{1}$, Azizati Rochmania ${ }^{1}$, Abdul Hafidz $^{1}$, \\ Kunjung Ashadi ${ }^{1}$ \\ \{anisa.17060474015@mhs.unesa.ac.id'1,nor.17060474095@mhs.unesa.ac.id ${ }^{2}$, \\ riniismalasari@unesa.ac.id $\left.{ }^{3}\right\}$ \\ Universitas Negeri Surabaya, Surabaya, Indonesia ${ }^{1}$
}

\begin{abstract}
This study aims to compare the physiological recovery strategies applied by coaches and provincial fencing athletes during the Covid-19 pandemic when carrying out Regional Training Center New Normal in welcoming PON (National Sports Week) 2021. The method applied in this research is quantitative and presented descriptively. Data were collected through an online questionnaire filled in by 20 samples and a structured oral interview as a complement. Three questions that have met the validity value include recovery (0.547), sleep (0.526), and hydration (0.585) and a reliability value of 0.919 . The data analysis technique uses the mean, percentage, standard deviation, homogeneity test, and difference test using One Way Anova on normally distributed data. The results showed that the application of physiological recovery for coaches and athletes had a value 0,781 ( $p>0.05)$. The conclusion shows that there is no significant difference between the application of physiological recovery between coach and athlete.
\end{abstract}

Keywords: physiological recovery, coach, athlete, fencing, covid-19.

\section{Introduction}

Currently the global pandemic has changed the life order of the world community. Diseases that have a broad impact when compared to SARS and MERS have a high transmission rate. The virus that started in December 2019 in the city of Wuhan and continues to spread throughout the universe to date has been reported from many other countries [1].

A novel infectious disease of the coronavirus family is identified in Wuhan, China in late December 2019, later called covid-19 (Chen et al, 2020). On January 30, who declared a global public health emergency. In February, outbreaks began in Iran, Italy, and other countries around the world. Then the epidemic turned into a pandemic and by the end of March half the world's population was in some form of lockdown. Based on WHO data on April 16, 2020, the total number of COVID-19 cases exceeded 2.1 million cases worldwide, without a total death toll of more than 135,000 [15].

The pandemic managed to spread to parts of the world in just a short time, one of which is Indonesia. Various losses are caused by this virus, especially in the world of sports which postpones sports competitions. The financial crisis experienced by the regions that host one of them is Papua, which is appointed as the organizer of PON 2020. A carefully designed period has to be adapted again so that it gives losses to both the coach and the athlete. The good side 
is the development of a web-based training program that makes it easier for organizations / clubs to sports players [34].

Maintaining physical fitness is very important in times of a pandemic like this, especially for an athlete. In addition to increasing immunity in the body, physical fitness also keeps the athlete's physical capacity from decreasing, one of which is fencing [25]. Emphasis and dexterity with weapons are characteristic of the sport of fencing. Therefore, this sport requires players to have agility, especially in the hands [33]. The important role of the hands and feet is focused in terms of attacking to defending. There are basic movements in playing fencing, namely the mastery of basic technique movements that are trained first without neglecting other techniques. This is because the majority of the frequency is done in competing and practicing [27].

Various kinds of efforts were made in order to get a good physical quality. Through a systematic and targeted training program, it will have a positive impact on the excellent physical quality of athletes so that it can have a good impact on mental health which can support athlete's technique [5]. Apart from that the physical guidance and aggressive nature of fencing causes considerable muscle damage. In professional fencing, athletes only have a limited period of time to recover from origin after training sessions and competitions [35].

Fatigue that is not immediately followed up through the right procedures can result in damage to cells and tissues in the body, especially during its growth period. Acute injuries also haunt future athletes (early retirement). This has an impact on the decline in athlete's performance to the region or country being defended. Therefore, the province which is the forerunner of the sport in East Java will become an obstacle before reaching the golden peak of achievement [17].

Poor recovery that is done over and over again will cause physical fitness problems. Various efforts are made before the competition so that athletes can perform optimally, including evaluation of techniques, tactics, athlete's nutrition, mastery of strategy and recovery. The basic foundation that must be possessed by coaches and athletes is knowledge of recovery. Correct recovery supported by knowledge can certainly support athlete performance [23].

Getting the right recovery after strenuous exercise can minimize injury to reduced performance. Therefore, the role of the coach in choosing a strategy physiological recovery must be adjusted to the athlete's motor development. The coach is expected to be more transparent to athletes by adding strategies physiological recovery in the training program along with the types of training that the athletes will apply. The mandatory thing that must be understood and known by coaches and athletes is timing the right so that the type of recovery is right on target [17].

As is well known, body mass index is one of the important factors that can help improve performance. The higher the body mass index can inhibit athlete's performance, especially fencing which requires agility in the game. Therefore, monitoring body weight needs to be considered because the weight gain of $1 \mathrm{~kg}$ within 24 hours shows that the recovery is going well. If there is a weight loss of $1 \mathrm{~kg}$, it shows that there is overtraining and the body needs a longer recovery. Conversely, increasing body weight exceeding $1 \mathrm{~kg}$ shows a light training load [32].

There is a problem, namely the limitations of the research literature that shows the facts of strategies physiological recovery during the covid-19 pandemic by analyzing the comparison of the application of recovery coaches and fencing athletes in East Java Province during the Covid-19 pandemic as a basis for further discussion. Therefore, it is important to do this research to determine the strategy physiological recovery. The renewal in this study lies in the 
research subject, namely the Provincial fencing team during the PNN (Regional Training Center for the scheme New Normal) during the pandemic Covid-19 as a material for further discussion. This research is important to do to determine the comparison of the effectiveness of the implementation of strategies physiological recovery carried out by coaches and fencing athletes of East Java Province during the pandemic Covid-19 in order to avoid decreased performance and avoid psychological disorders so that it can become a reference for clubs and the sports community so that they can maintain their strength hold the body well during the pandemic Covid-19.

\section{Method}

The method used in this research is quantitative with a descriptive approach. Target in the research of trainers and fencing athletes in East Java Province. Participation of respondents in this study amounted to 20 people consisting of 7 coaches and 13 athletes. The sample criteria are as follows:

1. Status as an active trainer and athlete of the Puslatda.

2. Following the PNN (Regional Training Center forschemeNew Normal) at Surabaya State University

The questionnaire used in this study is a questionnaire that has passed the validity test using Microsoft Excel version 365. Consists of 30 questions with indicators including recovery, sleep, hydration with a recovery value $(0.547)$, sleep $(0.526)$, hydration $(0.585)$ and a reliability value of 0.919 . Questions about recovery include the use of compressed garments, thermotherapy, cryotherapy, massage, and recovery activeduring the Covis-19 pandemic. while questions about sleep include sleep duration, consumption of milk before bedtime, use of light sleepers, conditions after waking up. and questions about hydration including checking hydration, taking supplements, consuming electrolyte and caffeine drinks before exercise, to sleep reminder apps. Data analysis techniques used in this study include maximum, value minimum, average, standard deviation, percentage, data normality test using the KolmogorovSminornov Test. The homogeneity test data for data differences uses One Way Anove. The flow of the research procedure is as follows, distributing the link to questionnairethe research sample via WhatsApp is a data collection method. Control and follow-up during data entry and structured oral interviews were the follow-up until data were collected. Data collection was carried out with a one shot case study in September 2020.

Daily activity during PNN (New Normal Regional Training Center) isis a topic in a structured interview. The results in the structured interview show that sleep patterns and eating patterns are more regular because they have been scheduled while in the dormitory, activities carried out outside of training are carried out in the dormitory such as relaxing, playing gadgets or watching dramas, this is due to limited access to in and out during PNN (concentration Area Exercises New Normal).

Furthermore, the data were analyzed using a percentage. Data analysis used SPSS version 23. The determination of the criteria for the level of application regarding the application of physiological recovery is presented in the following table:

Table 1. Scale application assessment of physiological recovery Category interval

\begin{tabular}{ll}
\hline Intervals & Category \\
\hline M-0.5 SD X M-1.5 SD & High
\end{tabular}




\begin{tabular}{ll} 
M-0.5 SD X $<M-0.5$ SD & Moderate \\
M-1.5 SD X $<M-0.5$ SD & Less \\
\hline
\end{tabular}

Source: Sriundy, 2015

Which one:

$\mathrm{M}=$ mean count

Elementary school is standard deviation

$\mathrm{X}=$ score obtained

\section{Result and Discussion}

After conducting research through online questionnaire regarding the comparison of strategies for physiological recovery coaches and provincial level fencing athletes who are shared with Google Form, the following discussion is carried out. The results of the calculation of the characteristics of the research subjects include age, weight, height and body mass index as shown in table 2.

Table 2. Characteristics of research subjects

\begin{tabular}{|c|c|c|}
\hline \multirow{2}{*}{ Subject characteristics } & \multicolumn{2}{|c|}{ Mean and SD } \\
\hline & Trainers & Athlete \\
\hline Age & $\begin{array}{c}40 \\
\pm 10.24\end{array}$ & $\begin{array}{c}20 \text { years } \\
{ }^{ \pm} 1.73\end{array}$ \\
\hline Height & $\begin{array}{c}166.46 \mathrm{~cm} \\
\pm 6.39\end{array}$ & $\begin{array}{c}169.28 \mathrm{~cm} \\
\pm 8.15\end{array}$ \\
\hline Weight & $\begin{array}{c}74.42 \mathrm{~kg} \\
\pm 10.29\end{array}$ & $\begin{array}{c}62.53 \mathrm{~kg} \\
\pm 9.99\end{array}$ \\
\hline BMI of & $\begin{array}{c}25.75 \mathrm{~kg} / \mathrm{m}^{2} \\
\pm 4.14\end{array}$ & $\begin{array}{c}22.46 \mathrm{~kg} / \mathrm{m}^{2} \\
\pm 2.59\end{array}$ \\
\hline
\end{tabular}

Based on the profile data of the research sample shown in table two, the average age of the subjects is 20 to 40 years. The first subject had an average body weight of $74.42 \mathrm{~kg}$ with a height of $166.46 \mathrm{~cm}$, while the second subject had an average body weight of $62.53 \mathrm{~kg}$ with a height of $169.28 \mathrm{~cm}$. It can be seen that the first subject has an average body mass index of $25.75 \mathrm{~kg} /$ which is included in the overweight category, while the second subject has a body mass index of $22.54 \mathrm{~kg} /$ which is in the normal category.

Table 3. description of respondents recovery, sleep, hydration

\begin{tabular}{ccccc}
\hline Variable & Subjects & Min & Max & Mean \&SD \\
\hline \multirow{2}{*}{ Recovery } & Trainers & 2 & 6 & $4.7 \pm 1.48$ \\
& Athlete & 1 & 13 & $5.7 \pm 3.57$ \\
\multirow{2}{*}{ Sleep } & Trainers & 3 & 7 & $4.8 \pm 1.24$ \\
& Athlete & 4 & 11 & $7.7 \pm 2.83$
\end{tabular}




$\begin{array}{ccccc} & \text { Coach } & 1 & 7 & 3.8 \pm 2.03 \\ \text { Hydration } & \text { Athlete } & 2 & 13 & 7.5 \pm 4.6\end{array}$

The data shown in table three shows that the average ratio of the application of recovery, sleep, and hydration in athletes is more dominant than that of coaches, as evidenced by the data that the average athlete who applies recovery is 5.7, while the coach has an average recovery of 4. , 7. “ The facts are reinforced by data on athletes who apply sleep and hydration with an average of 7.7 and 7.5 , while athletes have an average of 4.8 and 3.8 .

Table 4. Percentage of Recovery Aplication

\begin{tabular}{|c|c|c|c|c|c|}
\hline Interval & Category & Trainer & Percent & Athlete & Percent \\
\hline $\begin{array}{c}\mathrm{M}-0.5 \mathrm{SD} X \\
<\mathrm{M}-1.5 \mathrm{SD}\end{array}$ & Very High & 1 & $14 \%$ & 3 & $23 \%$ \\
\hline $\begin{array}{c}\text { M-0.5 SD X } \\
<M-0.5 \text { SD }\end{array}$ & High & 4 & $57 \%$ & 9 & $69 \%$ \\
\hline $\begin{array}{c}\text { M }-0.5 \text { SD X } \\
M-0.5 \text { SD }\end{array}$ & Moderate & 2 & $29 \%$ & 1 & $8 \%$ \\
\hline \multicolumn{2}{|c|}{ Total } & 7 & $100 \%$ & 13 & $100 \%$ \\
\hline
\end{tabular}

Based on Table four, it shows that the implementation of recovery by the majority coach is high with a percentage of $57 \%$ while the majority of athletes are high with a percentage of $69 \%$.

Table 5. Percentage of Sleep Application

\begin{tabular}{cccccc}
\hline Interval & Category & Trainer & Percent & Athlete & Percent \\
\hline $\begin{array}{c}\text { M-0.5 SD X } \\
<\text { M-1.5 SD }\end{array}$ & Very High & 4 & $57 \%$ & 4 & $31 \%$ \\
$\begin{array}{c}\text { M-0.5 SD X } \\
<\text { M-0.5 SD }\end{array}$ & High & 2 & $29 \%$ & 6 & $46 \%$ \\
$\begin{array}{c}\text { M-0.5 SD X } \\
\text { M-0.5 SD }\end{array}$ & Moderate & 1 & $14 \%$ & 3 & $23 \%$ \\
& Total & 7 & $100 \%$ & 13 & $100 \%$ \\
\hline
\end{tabular}

Based on the data in table five, it shows that the implementation of sleep recovery in the majority of coaches is very high with a percentage of $57 \%$ while the majority of athletes are high with a percentage of $46 \%$. 
Table 6. Percentage of Application Hydration

\begin{tabular}{rccccc}
\hline \multicolumn{1}{c}{ Interval } & Category & Trainer & Percent & Athlete & Percent \\
\hline M-0.5 SD X $<$ M-1.5 SD & Very High & 1 & $14 \%$ & 3 & $23 \%$ \\
M-0.5 SD X $<$ M-0.5 SD & High & 5 & $72 \%$ & 8 & $62 \%$ \\
M - 0.5 SD X M-0.5 SD & Moderate & 1 & $14 \%$ & 2 & $15 \%$ \\
Total & & 7 & $100 \%$ & 13 & $100 \%$ \\
\hline
\end{tabular}

Based on the data in table six, it shows that the application of recovery hydration in the majority of coaches is high with a percentage of $72 \%$ while the majority of athletes are high with a percentage of $62 \%$.

Table 7. Homogeneity and Normality

\begin{tabular}{lll}
\hline Sig & Test ofKolmogrov Smirnov & \\
\hline Variables & Recovery, sleep, hydration & \\
$\mathrm{P}$ & 0.999 & 0.724 \\
\hline
\end{tabular}

In table seven, it is known that the Kolmogrov-Smirnov significance value is sig recovery, sleep, and hydration (0.999) where the value is more than 0.05 , which means that the normality test on this data is normally distributed. Meanwhile, to determine whether there is an equation between coach and athlete variables. $\mathrm{P}$ is known to be 0.724 . based on the results of the Sig. 0.742, which value is more than 0.05 , which means the data is declared homogeneous.

Table 8. Difference test using One Way Anova

\begin{tabular}{cc}
\hline Sig & One Way Anova \\
\hline Variable & Coach and Athlete \\
$\mathrm{P}$ & 0.781 \\
\hline
\end{tabular}

The results of the One Way Anova difference test in table eight show the implementation of strategies recovery (recovery, sleep, hydration) on provincial level fencing trainers and athletes, it is known that the sig value is 0.781. Which (P>0.05) indicates that there is no significant difference in the application of physiological recovery between coaches and fencing athletes during the pandemic covid-19.

After the difference is performed by oneway anova and there is no significant difference between the application of physiological recovery coach and athlete. Data triangulation is also 
done for the equations of the application of physiological recovery. This indicates that the coach's instructions are already run by the athlete optimally so as to provide for the future performance of the athlete.

Based on research conducted on trainers and fencing athletes in East Java Province regarding physiological recovery with good categories then this can benefit sports physiology because it can support physical activity, minimize injury, and improve athlete performance (both physically and psychologically). Therefore, physiological quality affects achievement [16]. Often the training program provided by the coach contains several risks, especially if the athlete's physiology is not good so that it can cause physical injury. Lack of recovery time coupled with intense training results in both physical and psychological exhaustion. Athletes concentration will be disturbed from training to competition if they are stressed so that it has an impact on performance. The anxiety felt by athletes who do not have a history of injury is certainly different from athletes who have a history of injury [10].

Physiological measures can prevent athletes from drifting due to inadequate recovery, excessive stress, and potential illness. Coping with the stress experienced by athletes during thepandemicCovid-19 is one of the strategies recovery in this difficult time [11].There are various kinds of research on the treatment and its benefits for fatigue, muscle injury, physiological recovery, and performance improvement. According to Joanna Vaile and Shona Holson in the book Physiological Recovery, there are several and appropriate recovery strategies, including: recovery, sleep, and hydration. Recovery consists of cryotherapy, massage, compressent garments, thermoteraphy.

The application of cryotheraphyto the whole body (WPC) as a recovery modality for elite athletes can reduce pain in inflammatory conditions. Given the very cold air temperature from $-120 \mathrm{C}$ to $-150 \mathrm{C}$ in $2-3$ minutes it can cause strong physiological responses in users [20]. Four research studies found a significant reduction in muscle soreness, in relation to improved muscle function. Five articles report that Cryotheraphy (WBC) positively affects muscle function or performance capacity which in other ways adversely affects exercise mentally [29].

Compressent garment has been proposed to prevent performance degradation and improve recovery by speeding up nutrient delivery, improving post-workout edema, muscle soreness (DOMS), and muscle damage. The use of compressent garment can minimize the symptoms of muscle damage due to exercise (EIMD) which usually occurs as a result of unusual or eccentric exercise [4].According to Molly Winke et al [37]in their study, the muscle swelling assessed through changes in upper arm circumference was significantly lower in treatment compressed garment $(1.7$ vs $2.0 \mathrm{~cm}$ in compressed sleeves, $\mathrm{p}=$ 0.012).Interference ROM during Compressent Garments (PCD) treatment was lower and peak pain was $39 \%$ lower (27.5 mm in PCD compared to $45.2 \mathrm{~mm}$ in the compress arm (CS), p $<0.05$. using compressent garments further reduces the peak disturbance and recovery time from DOMS (Delayed Omzet Muscle Sorrenes).

There isa substantial treatment reduction thermo theraphy in fatigue. Through thermoteraphy helps athletes to get relief from muscle pain and joints with soft tissue, metabolic rate and also blood flow with vasodilation. Due to increased blood flow, oxygen uptake increases and can heal damaged tissue. A temperature of 36 degrees Celsius in 8-10 minutes will give a feeling of calming to the muscles. Thermoteraphy can be in the form of hot cloth, hot bottle, infrared, ultraviolet light, shortwave diathermy, heating pad, pussy tub water, sauna bath [31]. Faiz Shah Sharudin (30) in his research added that the data from fifteen studies were examined, and the overall quality. Immersion duration and water temperature showed an increase in recovery with a duration of 15 minutes with a water 
temperature of 15 limpc. The results showed good progress in athletes when the body temperature was more than 11 percent with the time of immersion. Thermotherapy (CWI) has a good effect on athletes including increased performance, reduced muscle soreness and fatigue.

Apart from cooling, sauna, compression to active recovery, the recovery strategy that is mostly used is massage. Massage can relieve muscle tension, reduce muscle soreness, and increase flexibility and range of motion (increases blood flow to muscles, improves cleansing of substances such as blood lactate or creatinie kinase). Here techniques such as efflurase, petrisage, tapotemnt, areusualapplied with thetotal duration of 10-30 minutes [26]. HouyongZhong [38] in his study of 12 athletes received massage sessions for 20 minutes with the comparison group in bed for the same time. The visual analogy scale ((VAS) on the normal scale for muscle fatigue, back muscle endurance, and pulse rate as parameters for stress index (SI), HRV indexs, SDNN, RMSSD, Pnn50, IF hf, DANJIKA / HF were analyzed. The results were 12 athletes (HF) were significantly higher immediately after the intervention than the LF control group. Therefore massage can facilitate recovery from muscle fatigue after training or competition for athletes.

Fahmi \& Ashadi [8] also added in his research that there was a significant difference in the ratio of reduction in lactic acid levels between the use of the method recovery with sport massage and cryotherapy with a $\mathrm{p}$ value $<0.05$. Where the average value of reducing lactic acid levels with sports massage was $4.92 \mathrm{nMol} / \mathrm{L}$ while cold water was $3.91 \mathrm{nMol} / \mathrm{L}$. There are many strategies for recovery, but sleep is the most significant strategy in avoiding overtraining. During sleep growth hormone and adrogens help for muscle repair, muscle building, and bone growth. Recommended sleep of 7-9 hours is sufficient to restore physiology (metabolism and inflammation), psychology (learning ability, motivation and memory). A 30-minute nap between 1:00 p.m. and 1:30 p.m., after only 4 hours of sleep a night leads to increased alertness and mental and physical performance. The drowsiness that is reported to be reduced after a nap and improved short-term memory can help restore physiological mechanisms to avoid significant muscle inflammation as well as maintenance of the immune system [21].

Lack of sleep negatively impacts the physical and psychological functions of the human body. Because sleep disturbances affect the release of hormones, hunger arises and leads to overeating. The balance of diet and body weight will be affected if athletes experience sleep deprivation for long periods of time. The immune system will be compromised and become weak, more diseases will become infected. In addition, poor sleep quality affects motor performance and increases the risk of injury. It negatively affects the circadian rhythm directly, as well as increased fatigue, decreased reaction time, and decreased maximal oxygen uptake (VO2max). Humans who don't get enough sleep have negative moods such as depression and decreased motivation which causes psychological stress. Previous studies have shown that negative moods directly affect athlete's performance. The emotional state that is regulated by the brain is very sensitive to the quality and quantity of sleep [24].

Studies report that improved sleep quality in athletes is associated with improved performance and overall success. Apart from minimizing injuries, optimizing health and improving performance can be achieved through increased participation in training. However, the majority of athletes fail to get the recommended sleep hours, thus threatening performance and health [19].

Apart from implementing recovery and sleep patterns, it is important to keep the body well hydrated. If the body is dehydrated it can cause thirst, nausea, vomiting, discomfort during exercise and fainting. What is more fatal is the disruption of the metabolic system if it 
occurs over a long period of time. Therefore the recommendation to meet fluids during physical activity can prevent dehydration. Apart from physical activity, fulfillment of hydration must be done every time, because the human body's construction is $70 \%$ fluid. If the body is well hydrated, energy transport, metabolism, and enzymes can run according to their function smoothly [22]. if the fluids in the body are not fulfilled and experience a decrease, it can result in not optimal body condition [28].

Ashadi Kunjung et al [2] in their research also reported that the average urine scale was 3.1 points, which means that only $31.2 \%$ of athletes are dehydrated. However, after exercising, the urine color index showed a scale of 4.1 . And $62.5 \%$ of athletes are dehydrated. The results showed that there was a significant change in the level of hydration before and after training. It can be concluded that prolonged exercise increases the risk of dehydration. It is important for athletes to meet the needs of body fluids so that there is no malfunction in the body during sports activities.

The amount of fluid that comes out can be influenced by temperature and humidity so it is necessary to calculate replacement fluids to keep the body hydrated. Therefore, it is necessary to know the right drinking pattern in order to reduce the bad effects of dehydration. [9] in their research stated that the drinking pattern that should be applied to a hot environment with an average temperature of $35.6^{\circ} \mathrm{C}$ with aerobic activity is the ad libtum drink drinking pattern. Ad libtum drinking pattern is better than poal drinking planned drinks.

The application of physiological recovery, knowledge related to physiological recovery needs to be improved. Knowledge regarding physiological recovery affects athlete's performance because providing a less than optimal recovery program can reduce athlete's performance and can even lead to the risk of injury [6].

As additional information, there is an obstacle in this study, namely the application of a broad-scale questionnaire. Therefore, it is hoped that the limitations of this study can be used as a basis for further research to make it better and use a broad scale in the future.

\section{Conclusion}

Based on the results of the research data analysis, it can be seen that there is no significant difference in the application of thestrategyphysiological recovery carried out between coaches and fencing athletes in East Java Province during the Covid-19 pandemic $(\mathrm{P}<0.05)$. Based on the above conclusions, coaches and athletes have implemented physiological recovery in the high category.

Suggestion. Based on the results of the research data analysis, it can be seen that the application of the strategy physiological recovery carried out by trainers and fencing athletes in East Java Province.

Based on the results of the discussion of coaches and fencing athletes in East Java Province regarding strategies physiological recovery during thepandemicCovid-19, efforts are needed to maintain these achievements, including providing variations to scheduling recovery. In addition, in order to maintain physical condition during a pandemic in order to maintain athlete performance, maintaining psychological health during a pandemic is necessary in order to reduce burnout during a pandemic. In addition to developing a training model, it is necessary to increase knowledge about recovery in order to obtain better results. 
Acknowledgments. The aouthor would like to thank the Faculty of Sport Science, Universitas Negeri Surabaya who has helped in providing funds for the publication of this scientific article so that article can be completed smoothly.

\section{References}

[1] Ainun RM, Nunung RM. Dampak Pandemi Covid-19 Terhadap Angka Pengganguran Di Indonesia. Academia.edu. 2020.

[2] Ashadi K, ND Mirza., Siantoro G. Hydration Status in adolescent runners: pre and post training. IOP Conference Series: Materials Science and Engineering. 2018.

[3] Bekti M. Penerapan Aplikasi Google Classroom, Google Form, Dan Quizizz Dalam Pembelajaran Di Masa Pandemi Covid-19. Jurnal Karya Ilmiah Guru. 2020.

[4] Brown F, Gisanne C, Howatson G, Van KS, Pedlar C, Hill J. Compressent Garments and Serveillance and Competition in Sport Protect Athelete and Staff During and After Pandemic. Journal of Functional and Kinesiology. 2017.

[5] Dhecvangga S, Rini I Perbandingan Hasil Tes Kondisi Fisik Atlet Anggar Tahun 2018 dan Tahun 2019 KONI Sidoarjo. Jurnal Prestasi Olahraga. 2020;3(3).

[6] Dias GA, Ashadi K. Pemahaman Pelatih Sekolah Sepakbola Se Kota Madiun Tentang Physiological Recovery. Jurnal Prestasi Olahraga. 2018.

[7] Selenia AF, Costa S., Montensano CF. The Effect COVID-19 Pandemic on Preceived Stress and Psycohobisoal States in Italy Athlete. International Journal of Sport and Exercise Psychology. 2020.

[8] Fahmi H, Ashadi K. Perbandingan Sport Massage dan Hydrotheraphy Cold Water Terhadap Physiological Recovery. JurnalOlahraga. 2019

[9] Febiyanti G, Ashadi K. Perbandingan Jenis Dan Pola Minum Terhadap Status Hidrasi Pada Remaja Laki-laki Dan Perempuan. Jurnal Olahraga. 2019.

[10] Hagen J, Jason DS, Guy WH. Covid -19 Serveillance and Competition in Sport: Utilizing Sport Science to Protect Athletes and Staff During and After Pandemic. Journal of Foundational and Kinesiology. 2020.

[11] Heindri J, Beckman J, Bertolo M, Brink MK, Kallus W. Multidimential Monitoring of Recovery Status and Implication for Performance. In International Journal of Sport Physiology and Performance. 2020.

[12] Herprandika, RP, Yuliawan, D, Rizky MY. The Analysis of Physical Conditions of Puslatkot Athletes of Kediri City for" Kediri Emas" in Porprov 2019. Jurnal SPORTIF.2019

[13] Hossein AM, Gazeni O, Moghadam AZ, Carlos JJS. Adressing Potential Impact of Covid-19 Pandemic on Physical and Mental Health of Elite Athlete. Elsevier Public Health Emergency Collection. 2020.

[14] Jasper FWC, Suofeng Y, Kin HK, Kelvin KWT, Hin C, Jin Y, Fanfan X, Jieling L, Cyril CYY, Rosana WSP, Hoi WT,Simon KFL, Kwok HC, Vincetnt KMP, Wan MC, Jonathan DI, Jian PC, Vincent CCC, Honglin C, Crishtopher KMHKwok YY. A Fa-Millial Cluster of Heneumonia Associated with the 2019 Novel Corona Virus Indicat-Ing-Person Transmission: A Study of A Family Cluster. The Lancet Origional Health.2020.

[15] Ketut IWS., Nyoman IK. Signifikansi Program Latihan Dalm Upaya Meningkatkan Performa Atlet. Seminar Nasional Riset Inovatif 2020. 2020.

[16] Kusumardhana., Buyung. Perbandingan Metode Recovery Aktif dan Metode Corstability Terhadap Asam Laktat. Jurnal of Sport and Exercise Science. 2018; 1(2).

[17] Latate M, Grace V, Duffeld R, Roach GD, Halson SL, Heals LJ, Sargent C. Can Sleep Be Used as an Indicator of Exess and Excess of Athlete Exercise? Frontiers in Physiology. 2018;99: 436.

[18] Watson MA. Sleep and Athletic Performance. Current Sport Medicinee Report. 2017;16: 413-418.

[19] Patriage ME, CookeJ., McKune A, Pyne BA. Whole-Body Cryotherapy: Potential to Enhace Athlete Preparation for Competition? Frontoers in Physiology. 2019.

[20] Marshall., JG Geoff MSc., Turner. The Important of Sleep for Athlete Performance. Strength and Conditioning Journal. 2016;38: 1.

[21] Mita LA, Ashadi K. Olahraga Di Lingkungan Indoor Pada Malam Hari Menghasilkan Rasio Keringat Lebih Banyak Dibandingkan Pagi Hari. Sport and Fitnes Journal. 2019 
[22] Musta'in M. Manajemen Cedera Akibat Olahraga Pada Pelajar SMA Sdo Kecamatan Pringsurat. JurnalPengabdianMasyarakat. 2020;6 (1).

[23] Mon DL, De AIRR, Hontora MG, Refoyo RI. The Immpact of Covid-19 and the effect of psychological factors on training conditionins of handball Players. Environ Public Health. 2020; 17:18.

[24] Nur MA. Survey Aspek Kebugaran Jasmani Kecepatan, Kelincahan, Dan Daya Ledak Atlet Bola Basket Kabupaten Bangkalan Di Masa Pandemik Covid-19. Prosiding SENOPATI. 2019;1: 17-21.

[25] Poppendick W, Wagmann M, Kellman M, Mark PF, Mater T. Massage and Recovery: A MetaAnalytical Review. 2016.

[26] Priya NBS. Analisis Gerakan Teknik Dasar Dalam Olahraga Anggar. Prosiding Seminar Biomekanika Olahraga. 2018.

[27] Raditya AM. Profil Hidrasi Atlet Pencak Silat PUSLATCAB Kabupaten Bangkalan Pada Sesi Latihan. Jurnal Prstasi Olahraga.2018.

[28] Rose C, Edewards MK, Siegler J. Whole-Body Cryotherapy As A Recovery Teechinique After Exrcise: A Review of Literature. International Journal of Sport Medicine. 2018;3: 14.

[29] Shah FS. The Effect of Cold-Water Immersion for Recovery on Sport Performance: A Systematic Review. Journal of Sports Medicine.2021.

[30] Sharma S. Thermotherapy: A Boom in Sport Injuries. International Journal of Yogic, Human, and Sport Science. 2019;4 (1).

[31] Suharjo. Aktivitas Fisik dan Recovery.Prosiding Seminar Hillrisasi Penelitian.Prosiding Seminar Hilirisasi Penelitian Untuk Kesejahteraan Masyarakat Lembaga Penellitian Universitas Negeri Medan. 2017.

[32] Supriyoko A, Mahardika W. Kondisi Fisik Atlet Anggar Surakarta. Jurnal Sportif: Jurnal Penelitian Pembelajaran. 2018;4:2.

[33] Susanto N. Pengaruh Virus Covid-19 TerhadapBidang Olahraga Indonesia. JurnalStamina. 2020;3:3.

[34] Tavares F, Brett TS, Drillee M. Fatigue and Recovery in Rugby: A Review. Sports Medicine. 2017.

[35] Widiowati A. Dechline G Latihan Shadow Fencing Anggar Provinsi Jambi. Journal Unja. 2018.

[36] Winke M, Williamson S. Comparison of a pneumatic compression device a compression garment during recovery from DOMS. International Jounal of Exercise Science. 2018;11:3.

[37] Zhong H, Eungpinichong W, Wang X. Effect of Meechanical- Bed Massage on Exercise-Induced Back Fatigue in Athletes. Journal of Physical TherapyScience. 2018;30:3. 